\title{
Indonesian Language Acquisition by Children in Melayu Riau: A Study of Systematic Errors
}

\author{
Maya Indah Wahyuni, Dedi Sutedi \\ Program Studi Pendidikan Bahasa Jepang \\ Universitas Pendidikan Indonesia \\ Bandung, Indonesia \\ mayaindah1981@upi.edu, dedisutedijepang@upi.edu
}

\begin{abstract}
This study aims to determine the process of acquiring a second language for children, by describing the gains made by children in the linguistic, and complete stages of competence. This study used descriptive-analytical methods. Data obtained directly and indirectly. Children sampled were children who lived in the area of Riau who have the first language of Malay. Based on the results of the analysis, language acquisition in children occurs in a natural sequence, regular sequence, and sequence of developments. Systematic error in this study has not been found because of undeveloped children's knowledge about vocabulary related to their environment. The systematic problem can be an omission error seen in the word "etina" spoken by the child. The child wants to say was the word "betina" but it is in phoneme sound removed / b / so that it was said to be "etina". The expansion of excessive language in the use of language also occurs, giving rise to false hypotheses that are influenced by children's cognitive abilities. This error was found in the phrase "Laut tunggu Abak antar mobilnya ya". The meaning of the word said by the child is to pick up the car located on the parking lot. So, there was a false concept between the word take and pick up in the child's mind. So, errors in acquiring a second language were influenced by cognitive abilities and environmental factors. Language acquisition was getting better with increasing the life experiences of a child.
\end{abstract}

\section{Keywords: acquisition, errors, Malay}

\section{INTRODUCTION}

In the first stage of life, a child acquires language from his mother. The mother tongue is the first language that is acquired and mastered directly. This process naturally occurs through daily communication so it does not require special time to study it (Dardjowidjojo, 2000). Language acquisition or acquisition in children is influenced by information-processing skills that are available and acceptable to their minds. In other words, language acquisition is influenced by a child's cognitive (Elliot, 1985; Umar, 2017).

Previous research acquisition was influenced by competence, performance, and family. Children's cognitive abilities are still limited, thereby affecting the language performance they use. Acquisitions get good results through family assistance(Nurjamiaty, 2015)
Lots of research on child acquisition, but this research focuses on the acquisition of Indonesian that occurs in children who speak Malay. This study is an analysis of sentence structure and acquisition errors spoken by children aged between three to five years in Riau. Some children have gone to playgroup and some have not. They have parents with teaching backgrounds.

The theory of acquisition in children includes theories of behaviorism, nativism, cognitivism, and interactionism. Behaviorism theory highlights aspects of linguistic behavior that can be observed directly in the relationship between stimuli (stimulus) and reactions (response). The theory of Nativism was put forward by Chomsky (as cited in Puspitasari \& Safitri, 2016, Umar, 2017). According to Chaer (2003) Cognitivism Theory, language is structured by reason. The sequence of cognitive development determines the order of language development. The acquisition of children is influenced by interrelated internal and external factors. The external factor is the second language environment. Internal factors are individual children, namely personality, age, motivation (Ellis, 2003; Puspitasari \& Safitri, 2016; Umar, 2017). There are five-second language acquisition hypotheses, namely the learning acquisition, monitoring, natural, input, and effective filtering hypothesis (Stephen Kreshen ${ }^{1}$, Stephen Krasen in Setyadi, 2013; Rusyani, 2008; Pranowo, 2017). Sakoda (2011) explains the sequence of second language acquisition namely natural order, acquisition sequence, regular sequence and there is also a sequence of developments.

Learners do not know the correct form is like what because of errors in the use of certain language systems that are applied in other languages (transfer), namely the removal of phonological systems, morphology, syntax and so forth Alwasilah \& Alwasilah, 2007). Mistakes are distinguished between errors and mistakes. Error is systematic, error correction requires guidance from competent people in the field of language or parents, for example. Mistake is more of a "slips of the tongue" mistake. "Mistake" is not systematic but is only temporary, and is sometimes realized by students. Correcting mistakes can be made by the learners themselves (Ellis as cited in Roidah, 2016).

The cause of language errors is interlanguage errors. One of the characteristics of "fossilization" is due to the language 
transfer (gengo ten i), Overgeneralization (Kajoo ippanka), Transfer of training (kunren-jo no Ten i), Learning strategy (Gakushuu sutorateji), Communication strategy (Komyunikeeshon Sutorateji) (Sakoda, 2011). Intruder errors are errors caused by the lack of mastery of the target language of the learner's self, not because of the transfer of language, which could be the influence of the points of the second language. So Richard (as cited in Roidah, 2016) categorizes language errors including overgeneralization, Ignorance of rule restrictions, Incomplete application of rules, False concept of hypothesized.

Errors can be corrected based on the way the surface structure is changed. Changes can be made using the Surface strategy Taxonomy proposed by Dulay et al (as cited in Roidah, 2016), namely Omission error, Additional error, stacking form error (Misordering error), wrong form (Misformation error).

\section{METHOD}

The research method used is descriptive-analytical. Qualitative research is descriptive in the form of written or oral words from people and observable behavior (Moleong, 2005). Descriptive research was conducted to describe, describe a phenomenon that occurs today by using scientific procedures to answer the problem (Sutedi, 2018). The technique used is observing samples in language, recording speech samples that are done directly or indirectly namely information obtained from his parents, analyzing the data in accordance with established theories.

The sample consisted of 5 children, aged between 3-5 years. Three children were studying at PAUD, two did not go to school. Parents' background, mother of 4 children works as a teacher, father of 1 child works as a teacher. These five children have Malay mother tongue.

\section{FINDINGS AND DISCUSSION}

\section{A. Phonology}

Humans listen to the words of the interlocutor one by one. The words that are heard are sounds that are spoken sequentially following other sounds. Sound has two different forms (Kashima as cited in Sutedi, 2014). First, the sound that is not related to humans, such as the sound of wind, vehicles, animals, and so forth. The two sounds related to humans, which consist of sounds that are unintentional and intentional. Unintentional sounds are sounds that do not use spoken devices such as stomach sounds, and sounds using spoken utensils such as sneezing, coughing and so on. Deliberate sounds are sounds that do not use utterances such as applause, beats and so on. While the sound that uses the utterance is the sound of the language (speech), whistling, coughing with a specific purpose. The sound of language has a message or a meaning. So that the sound of the language is used as a communication tool between humans. So that the sound of language understood by the speaker needs to go through the process of making it, the process of traveling to the ear (Sutedi, 2014).

\section{1) Additional error}

Children say the word cooking, the meaning of the word is making out or hugging. This word is uttered by children when they see two cats sleeping in each other's arms. "Kakak, tengok kucing itu, masak-masakan dia". The child added the word cooking, which shows the sequence of developments in obtaining the correct Indonesian. In the word, "tengok" is a word that is often used in the Malay area which means asking someone to see objects spoken by children. In terms of the word "tengok" there is the influence of the mother tongue spoken by children in the acquisition of Indonesian as a second language. To change the default, adjust the template as follows.

\section{2) Omission Error}

This error occurs in the "Ayam ini etina atau jantan, $B i$ ?" He asked the sex of the chicken he encountered while walking on the highway. The letter / b / which should have been sounded in the sentence was removed, so the word "etina" was pronounced. The meaning conveyed was "female". The pronunciation of the word "etina" is unconsciously and to improve this word is done by his father. Then in the sentence " Abi ada kecelaan di depan tuh." The word kecelaan comes from the word "celaan" the meaning is something that causes imperfect or criticism that is the word "gap" between the two objects. But the meaning expressed by the child is "kecelakaan" as an accident. In the word "kecelaan", syllables / $\mathrm{ka} /$ that should be pronounced are removed.

\section{Misordering error}

The sentence "Adek tidak bisa jalan disana, adek mau buta tadi ada batu" means that the child chooses another path because there is a stone blocking the road. So the word "buta" means "putar", in other words choose an alternative path because the road is blocked by rocks. So the meaning of the word in the sentence is "putar". But the word "buta" is said, so the meaning of the sentence is not accepted syntactically and pragmatically.

\section{Incorrect Form}

The child cannot distinguish the sound / $\mathrm{m} /$ and the sound / $\mathrm{n} /$. Because the ability of articulation that has not yet developed so that children equate the mention of sound / $\mathrm{m} /$ for sound / $\mathrm{n} /$. Seen in the sentence "Airnya sudah pemuh, Bak!" The word Bak in this sentence contains the meaning of Father, which comes from the word Abak not like a tub to collect water in the bathroom. The child calls on his father, that the water-filled in the bucket is full. In this case the natural hypothesis in the acquisition of phonology will develop according to its level.

Communication that is not understood by children causes difficulties when pronouncing words. This can be seen in the conversation that took place between Attar and his mother

Two errors occurred, which the child said. In the first error, a letter replacement occurred. 
Attar : "Abu, abu dimana?"

Ibu : " lagi masak didapur.?"

Attar : " Abu masak apa?

Ibu : "Masak sayur "

Attar : "Abu lagi masak sayur, ya tatan?"

Ibu : "ya, betul"

The letter / I / in the word "Ibu" is changed by the child to the letter / a / so that it becomes the word "Abu". In this word children present letters that are not appropriate. The second mistake, " $y a$, tatan" pronounced by the child is an affirmative word that comes from "ya, kan". To facilitate his own articulation the child replaces the word "kan" with "tatan" but there is a repeat of the syllable " $t a "$.

\section{B. False concept hypothesis}

When the child asks the mother to answer the question, the phrase "bunda, tanyalah" is said. In terms of the acquisition hypothesis-that is, language is mastered through an unconscious process (unconscious mind) (Rusyani, 2008). Cognitive children have not developed optimally so that children have not been able to distinguish the use of the word "ask" and "answer".

The use of the word yesterday and earlier is still not appropriate, and there is a change in the revelation sentence to the question sentence. This case was found "kemaren itu belajar, Nda?" This sentence takes the form of a question. Children ask about learning activities on the previous day. But the contextual meaning that the child wishes to convey is the learning activity that he did on that day or some time ago. So that the sentence that the child should say is "Sudah belajar tadi, Bunda". There is a deviation in the rules when children convey their intentions because children are interested in using the word "yesterday" instead of the word "earlier" so that it does not follow the existing grammatical rules.

The same thing is also seen in the phrase "Laut tunggu Abak antar mobilnya ya". The purpose of the words between the words spoken by children is to pick up a car that is located in the parking lot. So there is a false concept between the words "delivery" and "pick up" in the child's mind. So, errors in the acquisition of a second language, are influenced by cognitive abilities and environmental factors. Obtaining a language is getting better with the increasing life experience of a child.

Conversation between Raziq and his father

Ayah: "Adek, mau melewati jalan mana?

Raziq : "Kita belok kanan ya, Yah?"

Ayah: "tangan kanan adek mana?"

Raziq: "Ini” (sambil mengangkat tangan kanan nya)

Ayah: "Jadi, kalau kita lewat ke arah sini...artinya belok mana?

Raziq: “ Oia...salah adek.. belok $\underline{\text { kiri }}$ “

False concept hypothesis is found in the conversation between raziq and his father. This child is still experiencing errors in the concept of the use of right and left directions. "Turn right" is spoken but the contextual meaning he wants is "turn left".

\section{Overgeneralization}

When he was outside the house, he saw a tree that sways because of the wind, spontaneously the child says "Bunda, masuk cepat hari mau hujan". The child asks his mother to quickly enter the house for fear of getting rained on. In fact, the weather was not cloudy, only the wind blew through the trees so it swayed. This sentence was once spoken by his mother when the weather was cloudy, drizzling rain, and at the same time the tree also swayed. The passage of time this sentence is inherent in the child's mind. Finally embedded in his mind when he saw the swaying tree indicates that the rain will fall. In addition, there are also leveling the shape of the animal that he pronounced. In this case there was overgeneralization (Sakoda, 2011).

\section{Communication Strategy}

Raziq said "Banyak momo, bunda". Momo which is pronounced by a child means a cow. When a cow makes a "moo" sound, the child catches a sound like the word "momo" so that the cow is named "momo" in accordance with the sound of the cow he hears. So that in the child's mind is embedded that the cow is called momo. In this case, "fossilization" was seen from the child's communication strategy due to his lack of knowledge and ability. So, when the child was in the state of communication difficulties because he couldnot remember the words and expressions to be spoken, then he replaced/paraphrased them with other words.

\section{E. Foreign language input interference}

The sentence "Laut mau es krim, one aja, Bak!" Means that the child asks for a piece of ice cream from his father. Children use the word one as a substitute word for one in the Indonesian language. In the sentence " $B a k$, nak watermelon". Analyzed from the utterances of children, the word "nak" in Malay means "ingin", "watermelon" comes from the English language "watermelon", while "Bak" means father. This sentence is uttered when the child wants a piece of watermelon, he asked his father to buy a watermelon. The acquisition of Indonesian is influenced by the English that children have learned at school. So that there are inputs that affect the child's mind so that it clings tightly to the unconscious. This knowledge is one level higher than the child's cognitive ability. So that the Input Hypothesis occurs in children (Krashen in Setyadi, 2013)

When sleeping in the afternoon, the child invites his mother to take a shower, and says the phrase "mother, let's take a bath we go to school". In this case there is overgeneralization, children generalize that activities after waking up immediately take a bath then go to school, in the mind of the child this habit also applies after an afternoon sleep. The child who utters this sentence has undergone formal education in PAUD, so he has been introduced to the daily activities that he does through a song. The concepts in the song are embedded in children's thoughts. In the case of the theory of interactionism applies. Language acquisition is the interaction between children's abilities and the language environment. The language produced in children's thinking is 
a language that is obtained from the interaction of children with their teachers in PAUD, because teachers introduce songs about daily activities (Chomsky as cited in Puspitasari \& Safitri, 2016; Umar, 2017)

\section{F. Order Development}

In the sentence "Salah Bunda tu, kalo sudah bobok tu tidak bole tidur la." This means that the activities you do are not right, if you eat, you cannot go to sleep immediately. In this sentence two things can be reviewed, namely there is interlanguage or intermediary language that is in the minds of children for the word "bobok" which has the meaning of sleep. Children experience hypothetical concept errors. Children intend to say the word mamam for the word bobok. After this child is aware of his mistakes, he corrects the sentence "Salah Bunda tu, kalo sudah bobok tu tidak bole tidur la." the child still uses interlanguage which is his own language in his mind. Furthermore, his mother confirmed the sentence again by repeating the same sentence "sudah mamam tidak boleh bobok?" The child immediately answered with the acquisition of Indonesian, which is "ya, sudah makan tidak boleh tidur". It is understood that the sequence of a child's language acquisition, from the natural order, to the order of development by bringing up his own language or interlanguage.

The process of acquiring Indonesian by Riau Malay children has no difficulty because their language is almost the same as Indonesian. So that the acquisition process is impressed as Indonesian as the first language. But their first language is Malay, Indonesian is the second language for their daily lives. The differences that occur in these children are only the dialects they use, while the vocabulary used is exactly the same as the Indonesian language. Therefore, the acquisition of the Indonesian language found in this study is more to the cognitive development of children and errors that are errors of surface tactics (performance), or which can be noted through their utterances.

\section{CONCLUSION}

Words or sentences spoken by Malay children in the Riau region as a process of Indonesian language acquisition can be reviewed in terms of phonology, cognitive abilities and language acquisition processes. Phonological errors, namely errors in omissions, additions, malformations and stacking errors. Underdeveloped cognitive abilities cause conceptual errors in sentences or words spoken by children. In terms of the acquisition process, the communication strategy affects the child's speech, the input hypothesis received by the child is higher than cognitive abilities so that it influences the acquisition of Indonesian language. Subsequent research can be done in English language acquisition in children as a second language in terms of children's cognitive abilities and linguistics.

\section{REFERENCES}

Alwasilah, A. C., \& Alwasilah, S. S. (2005). Pokoknya menulis: Cara baru menulis dengan metode kolaborasi. PT Kiblat Buku Utama.

Chaer, A. (2003). Psikolinguistik:Kajian Teoretik. Jakarta: Rineka Cipta

Dardjowidjojo, S. (2000). Echa: Kisah pemerolehan bahasa anak Indonesia. Jakarta: Unika Atma Jaya.

Elliot, A. .J. (1985).Child language. Cambridge: Cambridge University Press

Ellis, R. (2003).Understanding second language acquisition. Walton Street Oxford. Oxford University Press.

Moleong, J. L. (2005). Metodologi penelitian kualitatif. Bandung: Remaja Rosdakarya.

Nurjamiaty, N. (2015). Pemerolehan bahasa anak usia 3 tahun berdasarkan tontonan kesukaannya ditinjau dari konstruksi semantik. Jurnal Edukasi Kultura, 2(2), 42-62.

Pranowo. (2017). Teori belajar bahasa untuk guru bahasa dan mahasiswa jurusan bahasa. Yogyakarta: Pustaka Pelajar.

Roidah, I. (2006). Analisis kesalahan gramatikal dalam hasil karya tulis mahasiswa jurusan bahasa inggris di sekolah tinggi keguruan swasta di Jakarta. (Unpublished master's thesis). Universitas Pendidikan Indonesia.

Rusyani, E.(2008). Pemerolehan Bahasa Indonesia anak usia 2,5 tahun (Studi kasus terhadap pemerolehan bahasa anak usia dini). (makalah). Jurusan Pendidikan Luarbiasa Fakultas Ilmu Pendidikan, Universitas Pendidikan Indoesia.

Puspitasari, R. H. \& Safitri, P. I. (2016). Penguasaan bahasa pertama (mother tongue) pada batita dan balita transmigran asal Jawa di Silat Kapuas Hulu Kalimantan Barat: Kajian psikolinguistik. Prosiding PRASASTI, 646-652.

Sakoda, K. (2011). Nihongo kyoiku ni akasu daini gengo shutoku kenkyu [studies on second language acquisition for japanese education].Tokyo: ALC.

Setiyadi, A. C., \& Salim, M. S. U. (2013). Pemerolehan bahasa kedua menurut stephen krashen. At-Ta dib, 8(2). 265-279.

Sutedi, D. (2014). Dasar-dasar linguistik bahasa jepang. Bandung: UPI Press dan Humaniora.

Sutedi, D. (2018). Penelitian Pendidikan Bahasa Jepang. Bandung: UPI Press dan Humaniora.

Umar, A. (2017).Hakikat bahasa dan pemerolehan bahasa. Sumber belajar penunjang PLPG 2017 Mata Pelajaran/ Paket keahlian Bahasa Indonesia. Jakarta: Kemdikbud dirjen GTK 